\section{Famine: the distant shadow over French psychiatry}

\author{
J. L. T. BIRLEY
}

In August 1999, the World Psychiatric Association held its international congress in Hamburg, the first to have been held in Germany. It provided an opportunity, bravely taken, to report on, and mount an exhibition of, the abuses of psychiatry during the Nazi rule between 1933 and 1945. International historical research has revealed a great deal over the past 30 years, and there was much to discuss - a painful but necessary process for the future of German psychiatry.

Vichy France has long been studied by professional historians, but Vichy psychiatry and, in particular, the serious famine in its hospitals between 1940 and 1944, has only recently received such attention. I know of no publications in English on this topic. Yet it was in England that one of the first and most dramatic protests was made.

On 24 August 1943, Simone Weil, the distinguished French philosopher, died aged 34, in Ashworth Sanatorium. She had starved herself, insisting that she should suffer with her compatriots across the Channel, whose official rations amounted to 1200 calories per day, insufficient to support life. French citizens went hungry, but did not starve to death - they were expected to obtain extra food in various ways. Many groups were allowed extra rations: the young, heavy labourers, pregnant and nursing mothers and hospital patients. But not all hospital patients. Those in psychiatric hospitals were specifically excluded. Their death rate rose dramatically.

French psychiatrists reported what was happening at the time, largely in detached, clinical terms, to avoid the censor. They described famine oedema; and famine behaviour - fighting round the food trolleys, eating anything (grass, dust, faeces, even their own fingers) and a profound lethargy. In a review of the publications in the Annales Medico-Psychologiques during the Vichy years, Gourevitch (1995) reported that 'articles on starvation in the hospitals featured more than any other topic'.

After 1945, the events were forgotten, or suppressed, and it was over 40 years before the first systematic study was published, in 1987. The author, Max Lafont, a psychiatrist working in Lyon, gave his book a provocative title, L'Extermination Douce (Lafont, 1987). Comparing the overall death rates in psychiatric hospitals during the pre-war period with those during Vichy rule, he estimated that the excess mortality amounted to some 48000 French citizens. A new edition of his book has since been published (Lafont, 2000). It is a sequel, containing the core of his original findings and reviewing the comments and criticisms which followed their publication.

Was this 'an extermination' - a deliberate policy of the Vichy government? The guilt, if there is any, is at present only that of association. Pétain was an admirer and supporter of Dr Alexis Carrel, a Nobel prizewinner and an extreme advocate of eugenic measures, believing that 'families where there exists syphilis, cancer, tuberculosis, neurosis and feeble-mindedness are more dangerous than those of thieves and assassins' (Carrel, 1935). In 1941, with Pétain's approval and patronage, Carrel set up 'The French Foundation for the Study of Human Problems'. But there is no evidence that he had any direct influence on Vichy policy. Vichy officials could exert their influence. The wife of Max Bonnafous, who was concerned with food supplies, worked at Auxerre hospital, where the rations were increased (Scherrer, 1980).

Did any psychiatrists protest? This was a risky thing to do, but some of them did so, and reported their experiences at meetings of the Sociéte Medico-Psychologique. In October 1941, their protests were sufficiently loud for its committee to go into secret session, probably to prepare some complaint to the authorities. The details of this session remain undisclosed, but whatever was decided, it had no discernible effect.

Some superintendents took effective action, increasing the productivity of their farms, or making good use of the black market. The mother superior of the hospital at Le Puy had prudently purchased, before the occupation, the entire cargo of a barge carrying rice. Others did much less, leading to some bizarre incongruities, like those of the Irish and Indian famines, where food was exported from a starving land. At the Vinatier Hospital, Lyon, where 2000 patients died, the superintendent made great efforts to develop a protein from blood collected at local abbatoirs, while insisting that the farm's considerable produce be sold, to increase the income of the already wealthy hospital.

After the war there was much work to do and many scores to settle, and the fate of those with mental illness who were institutionalised was not a high priority. No official inquiry on this episode has ever been set up, either in the immediate postwar years, or in response to Max Lafont's 1987 publication. The present director of the Vinatier Hospital, Dr Patrick Lemoine, published a novel aimed at a wider public. It was a 'faction' - based on the hospital's copious records and the reminiscences of its staff - in the form of letters between a nurse and a man working on the farm, who later worked in the wards and fought in the Resistance. Droits d'Asiles (Lemoine, 1998) makes vivid reading and won a prize, but led to no significant response.

Is any response, or official inquiry, necessary? Perhaps the task should be left to professional historians, better equipped than psychiatrists to detect and interpret the evidence of the past. Their expertise was essential in revealing the full extent of the Nazi abuses, and Vichy psychiatry is beginning to receive their attention.

A volume from the Institut d'Histoire du Temps Présent on the 'time of restrictions' in France includes a report on the hospital at Clermont in l'Oise, a rural area which in general did not suffer severe shortages (Besse, 1996). In this large and crowded hospital (3750 patients in the summer of 1940) the annual mortality rose from a pre-war average of $5 \%$ to $12 \%$ in 1940 and $26 \%$ in 1941, remaining around $18 \%$ for the next 3 years. The most severe shortages were in animal proteins - the weekly meat ration falling from $250 \mathrm{~g}$ to 90 g. (The skeletal survivors, similar to 
those of a Nazi camp, are pictured on the front cover of Max Lafont's recent book.) This volume also includes a study of the Bouches du Rhône (Menchérini, 1996) an area where there was little local agriculture, and which was therefore dependent on imports from other parts of France. Menchérini reports much more severe shortages among the entire population of Marseilles, with rickets affecting $23 \%$ of children under 3 years of age, and a mortality of $45 \%$ in the psychiatric hospital in 1941.

Another historian, Samuel Odier, has found a letter from an official in Vichy's Health Department to a protesting Superintendent of St Egrève Hospital near Grenoble (Odier, 1992). He is told that 'increased rations should only be given to those patients who are likely to recover sufficiently to be discharged and take their place in society'. The rest, it is implied, are useless mouths.

In 1997, Dr Bernard Glorion, the President of the Conseil de l'Ordre de Médecins, made a public apology for his

J. L. T. BIRLEY, FRCPsych, Upper Bryn, Longtown, Hereford HR2 ONA, UK

(First received 30 July 200I, accepted I October 200I)

organisation's active support of the removal of Jewish doctors from their posts - a decision made in August 1940 by the Vichy government, not by the Germans. Perhaps some more apologies for what happened in those years are still waiting to be made.

\section{DECLARATION OF INTEREST}

None.

\section{REFERENCES}

Besse, J.-P. (1996) L'exemple de l'hôpital psychiatrique de Clermont dans l'Oise. In Le Temps des Restrictions en France 1939-49 (eds D. Veillon \& J.-M. Flonneau), pp. 433-436. Cahiers 32-33, Cahiers de l'Institut d'Histoire du Temps Présent. Cachan: Institut d'Histoire du Temps Présent.
Carrel, A. (1935) L'Homme, cet Inconnu. Paris: Plon.

Gourevitch, M. (1995) Les Annales MédicoPsychologiques sous Pétain. Perspectives Psychiatriques, 46, 27-31.

Lafont, M. (1987) L'Extermination Douce. Ligné: Editions Ligné AREPFI.

- (2000) L'Extermination Douce. Bordeaux: Editions le Bord de l'Eau.

Lemoine, P. (1998) Droits d'Asiles. Paris: Editions Odile Jacob.

Menchérini, R. (1996) Conséquences sanitaires et sociales dans les Bouches-du-Rhône. In Le Temps des Restrictions en France 1939-49 (eds D. Veillon \& J.-M. Flonneau), pp. 419-432. Cahiers 32-33, Cahiers de I'Institut d'Histoire du Temps Présent. Cachan: Institut d'Histoire duTemps Présent.

Odier, S. (1992) Conditions Matérielles d'Internement dans un Hôpital Psychiatrique (1930-1960). Thesis for Master's Degree. Lyon: University of Lyon II.

Scherrer, P. (1980) Un Hôpital sous l'Occupation. Paris: Atelier Alpha Bleue. 